\title{
Effect of Static and Cyclic Loading on Behavior of Fiber Reinforced Sand
}

\author{
H.N Ramesh, Dr.L.manjesh, Vijaya Kumar.H.A. \\ Professor, Faculty of Civil engineering, Bangalore University, \\ Associate professor, Faculty of Civil engineering,Bangalore University, \\ ${ }^{3}$ (Research Scholar, Faculty of Engineering -Civil, U V C E, Bangalore University, Bangalore, India) 560056
}

\begin{abstract}
Foundations are often constructed in various sub soil conditions and subjected to static loads due to various structures supported by the foundation. In some circumstances in addition to static loads the foundations are subjected to dynamic loads like machine loads, seismic loads and moving wheel loads. The static behaviors of foundations are explored in detail but not much work was reported on the cyclic behavior of foundations. In this paper an attempt is made to evaluate the static and cyclic behavior of circular footing resting on sand and clay subgrade by conducting plate bearing and cyclic plate load tests in large model box tests. The load displacement characteristics were found from static plate bearing tests from which modulus of subgrade reaction was found which is used in pavement design and evaluation. Also from cyclic plate load tests coefficient of elastic uniform compression $\left(\mathrm{C}_{\mathrm{u}}\right)$ was evaluated which is a parameter used in the design of machine foundations. In the present study the plate bearing and cyclic plate load tests are conducted for layered soils such as sand overlain by $\mathrm{BC}$ soil. The dynamic response was evaluated in terms $\mathrm{C}_{\mathrm{u}}$ it is increased from $0.70 \times 10^{6} \mathrm{kN} / \mathrm{M}^{3}$ for unreinforced sand to $1.41 \times 10^{6} \mathrm{kN} / \mathrm{M}^{3}$ for reinforced sand similarly, for BC soil it is increased from $0.21 \times 10^{6}$ $\mathrm{kN} / \mathrm{M}^{3}$ to $0.56 \times 10^{6} \mathrm{kN} / \mathrm{M}^{3}$ for Stabilized BC soil.
\end{abstract}

Keywords: - Cyclic plate load tests, Co-efficient of Elastic uniform compression, California Bearing ratio, Modulus of sub grade Reaction.

\section{INTRODUCTION}

The subgrade of highway or foundation of structures require the special attention of the civil engineer when subjected to weight of machine or vehicle and the foundation loads are dynamic nature in addition to static loads. Dynamic analysis to evaluate the response of earth structures to dynamic stress applications, such as those produced by machine loads, seismic loads and moving wheel loads are finding increased application in civil engineering practice.As it is well established that a foundation weighs several times as much as a machine, a dynamic load associated with the moving parts of a machine is generally small as compared to its static load. In this type of foundation a dynamic load applies repetitively over a large period of time but its magnitude is small, and it is therefore necessary that the soil behavior be elastic, or else deformation will increase with each cycle of loading until the soil becomes practically unacceptable. Similar type of loading can be expected on pavement, the moving wheel loads are dynamic in nature due to repeated application of moving wheel loads the settlement of soil subgrade will increase with each application and finally leads to the subgrade failure. In dealing with these type of loads the co-efficient of elastic uniform compression of soil $\mathrm{Cu}$ is the most important parameter to be determined which can calculated by cyclic -plate -load test in the model box. An attempt has been made in this paper to study a point of this phenomenon. In the current research, two types of tests on circular plate subjected to Cyclic and static loads are performed. However, the main objective of the present study is to evaluate the dynamic elastic constants of locally available sand with fiber reinforcement using large scale model box.

\section{LITERATURE REVIEW}

Review of the literature revealed that various laboratory investigations have been conducted on fiber reinforced materials but these investing ations were limited in their scope and concentrated on soil reinforcement for back fill.Gray.D.H. and Al- Refeai (1986)., [1]. Reported that the critical confining stress was a function of the surface friction properties of fibers and soil.Gabr M.A. and John H. Hart (2000)., [2] -Have conducted nine plate load tests and evaluated the elastic modulus of Geogrid-Reinforced sand for different $\mathrm{U} / \mathrm{b}$ Ratios.Gray.D.H. and Ohashi (1983)., [3]. Investigated that increased shear strength, increased ductility and reduced post peak strength loss due to the inclusion of discrete fibers. The inclusion of discrete fibers increased both the cohesion and the angle of internal friction of the specimen.Gray.D.H and Maher.M.H. (1989)., [4] Reported that curvilinear failure envelops for rounded sands and bilinear failure envelops for angular sands. 
They established that the failure surface of fiber-sand composite was planar and oriented in accordance with the coulomb criterion which suggests isotropic reinforcing behavior. Moghaddas Tafreshi.S.N. et al (2008)., [5] Presented the results of cyclic - footing - load tests from the laboratory - model tests on square footings supported by sand bed. The results indicate that with increasing the relative density of soil the value of $\mathrm{Cu}$ increases. Rosa .L Santoni and Steve Webstor (2001).,[6].Concluded that the inclusion of randomly oriented discrete fibers significantly improved the UCC strength of sand and a maximum performance was achieved at a fiber dosage rate between 0.6 and $1 \%$ dry weight and the inclusion of up to $8 \%$ of silt does not affect the performance of the fiber reinforcement. Radoslaw .L and Jan Cermak (2003)., [7] -Developed a model for prediction of the failure stress in triaxial compression. The failure envelop has two segments; a linear part associated with fiber slip, and a nonlinear one related to yielding of the fiber material. Rosa L. Santoni. and Steve L.Webstor. (2001)., [8] -Concluded that the inclusion of randomly oriented discrete fibers significantly improved the UCC strength of sand. Maximum performance was achieved at a fiber dosage rate between 0.6 and $1 \%$ dry weight and finally, the inclusion of up to $8 \%$ of silt does not affect the performance of the fiber reinforcement.Ranjan et al (1996)., [9] Reported that reinforcement of medium sand was less effective than fine sand.

\section{MATERIALS AND METHODS}

The sand used for the investigation was brought from a construction site near Hebbal about $10 \mathrm{Km}$ from Bangalore City, Karnataka (State), the density of sand was $16.4 \mathrm{KN} / \mathrm{m}^{3}$ was used for all the tests and the fiber used was fibrillated polypropylene fibers. The properties of the sand in un reinforced condition and as sand fiber composite was determined by standard dry sieving as well as triaxial test as per relevant Indian Standards (Table 1\&2). The salient features and properties of fibers are listed in Table 2 and Plate 1 shows the view of the model box. The length of the fiber used was $50 \mathrm{~mm}(\mathrm{Ref})$

\subsection{Test-set-up}

A galvanised iron tank of size $1.2 \times 1.2 \times 1.0 \mathrm{~m}$ was used in the present study. The side of the model box was stiffened by providing two diagonal struts of steel angle sections on each side. For testing the model box a self straining type of loading frame of 5T capacity and a mechanical jack was used for performing static and cyclic plate load tests. A $300 \mathrm{~mm}$ circular steel plate was used to exert pressure on the prepared sand bed, the experimental test set up is shown in plate no1,

\subsection{Test Specimens.}

3.3.1Unreinforced sand specimen: The total depth of $500 \mathrm{~mm}$ sand bed was prepared in the tank by placing the sand in $100 \mathrm{~mm}$ lift to the desired density by rainfall technique and again same procedure is repeated for the next layers to get the total required Depth.

3.3.2 Reinforced specimen: The sand-fiber composite is prepared by uniformly hand mixing the known quantity of sand with $0.5 \%$ of fiber and then the mix is deposited inside test tank in layers of small thickness and each layer is compacted to achieve atleast $95 \%$ of the MDD.

\subsection{Methods:}

The tests were performed in a well stiffened square steel tank specially fabricated in such a way that its size is five times that of the diameter of the plate. The experimental test set up is shown in plate 1 . The characteristic of sand is as given in Table 1 and the characteristics of reinforcing material and other details are shown in Table 2.Static and Cyclic plate load tests were carried out as per IS 5249:1992.All the tests were conducted on the model box using $300 \mathrm{~mm}$ dia circular plate. The load deflection values were recorded by applying incremental loads through the hydraulic jack. From static plate load test the modulus of sub grade Reaction (K) is obtained, and From Cyclic Plate Load test, the co-efficient of elastic uniform compression of soil $\mathrm{C}_{\mathrm{u}}$ is obtained. Both these $(\mathrm{K} \& \mathrm{Cu})$ parameters are important in designing the pavement and structures.

\section{RESULTS AND DISCUSSIONS.}

Modulus of Subgrade Reaction (K) of both Reinforced and Unreinforced sand and BC soil is obtained by conducting Static Plate load test, Similarly co-efficient of elastic uniform compression $(\mathrm{Cu})$ of Reinforced and unreinforced sand and BC soil is obtained by conducting Cyclic plate load test. Fig 1, 2 and 8 shows the Load-settlement curve obtained from static plate load test, from these curves ultimate bearing capacity and modulus of subgrade reaction $(\mathrm{K})$ is determined. The ultimate bearing capacity of unreinforced sand is $1400 \mathrm{kN} / \mathrm{M}^{2}$ tested at the density of $16.4 \mathrm{kN} / \mathrm{M}^{3}$ and modulus of subgrade reaction $(\mathrm{K})$ is $16.96 \times 10^{4} \mathrm{kN} / \mathrm{M}^{3}$. When the sand is reinforced with $0.5 \%$ fiber, the ultimate bearing capacity is found to be $1900 \mathrm{kN} / \mathrm{M}^{3}$ corresponding to the density of $16.2 \mathrm{kN} / \mathrm{M}^{3}$ and modulus of subgrade reaction $(\mathrm{K})$ is increased to $17.88 \times 10^{4} \mathrm{kN} / \mathrm{M}^{3}$. Fig $3,4,7$ and 9 shows the cyclic loading curve these curves were plotted for each set of loading and unloading, hence 
hysteresis loops were obtained for the test series. This sequential loading and unloading made it possible to separate the recoverable component $(\mathrm{Se})$ and non recoverable component $(\mathrm{Sp})$ of the settlement of the plate for different load levels.Fig 5 and 6 is obtained by plotting pressure (P) v/s elastic rebound (Se), co-efficient of elastic uniform compression $(\mathrm{Cu})$ is then determined by the relations $\left[\mathrm{C}_{\mathrm{u}}=\frac{p}{s_{e}}\right] \mathrm{kN} / \mathrm{M}^{3}$. Due to fiber reinforcement the $C_{u}$ values of sand is increased from $0.70 \times 10^{6} \mathrm{kN} / \mathrm{m}^{3}$ for unreinforced sand to $1.41 \times 10^{6}$ $\mathrm{kN} / \mathrm{M}^{3}$. Similarly after stabilization of BC Soil the same is increased from $0.21 \times 10^{6} \mathrm{kN} / \mathrm{M}^{3}$ to $0.56 \times 10^{6} \mathrm{kN} / \mathrm{M}^{3}$.

\section{List of Tables:}

Table 1 Basic Properties of Sand

Table 2 Properties of Polypropylene Fiber

Table 3Load V/s Settlement Values (Unreinforced)

Table 4Load V/s Settlement Values (Reinforced)

Table 5Cyclic Plate Load Test Result (Unreinforced)

Table 6 Cyclic Plate Load Test Result

\begin{tabular}{|c|c|}
\hline Particulars & Description Values \\
\hline Material & Polypropylene \\
\hline Type & Fibrillated \\
\hline Colour & White \\
\hline Sp Gravity & 0.91 \\
\hline Elongation at Break & $20 \%$ \\
\hline Length Evaluated & $50 \mathrm{~mm}$ \\
\hline Tensile strength & $3,10,275 \mathrm{Kpa}$ \\
\hline Young`s Modulus & $4,826,500 \mathrm{Kpa}$ \\
\hline
\end{tabular}

Table 1 Basic Properties of Sand

\begin{tabular}{|c|c|c|}
\hline Sl & Properties & \\
No & $4.75 \mathrm{~mm}$ & \\
\hline 1. & Sieve Analysis \% Passing & 89.06 \\
& $2.36 \mathrm{~mm}$ & 70.28 \\
& $0.6 \mathrm{~mm}$ & 52.26 \\
& $0.3 \mathrm{~mm}$ & 19.50 \\
& $0.075 \mathrm{~mm}$ & 7.78 \\
& Liquid Limit \% & 3.28 \\
\hline 2. & Plasticity Index\% & --- \\
\hline 3. & $\mathrm{NP}$ \\
\hline 4. & O M C \% & 10 \\
\hline 5. & Max.Dry Density & $16.4 \mathrm{kN} / \mathrm{m}^{3}$ \\
\hline 6. & CBR\% & 6.00 \\
\hline 7. & IS HRB \% & $\mathrm{A}-6$ \\
\hline
\end{tabular}

Table 2: Properties of Polypropylene Fiber

\begin{tabular}{|c|c|}
\hline Load In KNs & $\begin{array}{c}\text { Settlement in } \\
\text { MM }\end{array}$ \\
\hline 0 & 0 \\
\hline 2.5 & 0 \\
\hline 5 & 0.1 \\
\hline 7.5 & 0.3 \\
\hline 10 & 0.7 \\
\hline 12.5 & 1.2 \\
\hline 15 & 1.8 \\
\hline 17.5 & 2.5 \\
\hline 20 & 3.1 \\
\hline
\end{tabular}

Table 3: Physical Properties of BC soil. 


\begin{tabular}{|l|c|}
\hline Colour & Black \\
\hline Grain size distribution : & 2.00 \\
Gravel, \% & 38.20 \\
Sand, \% & 59.80 \\
Silt and Clay, \% & \\
\hline Atterberg's limits: & 46.6 \\
Liquid limit, \% & 24.81 \\
Plastic limit, \% & 21.79 \\
Plasticity index, \% & 16.97 \\
Shrinkage limit, \% & \\
\hline Compaction characteristics: & 1.67 \\
Maximum dry density (g/cc) & 20.08 \\
Optimum moisture content, \% & \\
\hline CBR,\% & 3 \\
\hline Unconfined compressive strength & 101.00 \\
(kN/m $^{2}$ ) at OMC and MDD & \\
\hline
\end{tabular}

Table 4: Load V/s Settlement Values (Unreinforced Sand)

Modulus of subgrade Reaction for Unreinforced Sand, $\mathrm{K}=\frac{p}{\Delta}=\frac{2.12}{0.125}=16.96 \mathrm{Kg} / \mathrm{cm} 2$ or $\mathrm{K}=16.96 \times 10^{4} \mathrm{kN} / \mathrm{m}^{3}$

Table 5: Load V/s Settlement Values (Fiber Reinforced Sand)

\begin{tabular}{|c|c|}
\hline Load In KNs & Settlement in MM \\
\hline 0 & 0 \\
\hline 2.5 & 0 \\
\hline 5 & 0 \\
\hline 7.5 & 0.1 \\
\hline 10 & 0.2 \\
\hline 12.5 & 0.3 \\
\hline 15 & 0.5 \\
\hline 17.5 & 1.3 \\
\hline 20 & 1.8 \\
\hline
\end{tabular}

Modulus of subgrade Reaction, $\mathrm{K}=\frac{p}{\Delta}=\frac{2.23}{0.125}=17.88 \mathrm{Kg} / \mathrm{cm} 2=17.88 \times 10^{4} \mathrm{kN} / \mathrm{m}^{3}$

Table 6: Cyclic Plate Load Test Result (Unreinforced Sand)

\begin{tabular}{|c|c|c|c|}
\hline \multicolumn{4}{|c|}{ FIRST CYCLE } \\
\hline \multicolumn{2}{|c|}{ loading } & \multicolumn{2}{|c|}{ unloading } \\
\hline Load in $\mathrm{KNs}$ & Settlement in $\mathrm{mm}$ & Load in $\mathrm{KNs}$ & Settlement in $\mathrm{mm}$ \\
\hline 0 & 0 & 0 & 0.03 \\
\hline 2.5 & 0.1 & 2.5 & 0.1 \\
\hline \multicolumn{4}{|c|}{ SECOND CYCLE } \\
\hline 0 & 0.33 & 0 & 0.165 \\
\hline 5 & 0.22 & 5 & 0.22 \\
\hline \multicolumn{4}{|c|}{ THIRD CYCLE } \\
\hline 0 & 0.165 & 0 & 0.175 \\
\hline 5 & 0.22 & 5 & 0.305 \\
\hline 7.5 & 0.345 & 7.5 & 0.345 \\
\hline \multicolumn{4}{|c|}{ FOURTH CYCLE } \\
\hline 0 & 0.175 & 0 & 0.385 \\
\hline 5 & 0.255 & 5 & 0.435 \\
\hline 10 & 0.5 & 10 & 0.5 \\
\hline
\end{tabular}


Table 7: Cyclic Plate Load Test Result (Fiber Reinforced sand)

\begin{tabular}{|c|c|c|c|}
\hline \multicolumn{4}{|c|}{ FIRST CYCLE } \\
\hline \multicolumn{2}{|c|}{ loading } & \multicolumn{2}{|c|}{ unloading } \\
\hline $\begin{array}{c}\text { Load } \\
\text { in } \\
\text { KNs }\end{array}$ & $\begin{array}{l}\text { Settlement } \\
\text { in } \mathrm{mm}\end{array}$ & $\begin{array}{l}\text { Load } \\
\text { in } \\
\mathrm{KNs}\end{array}$ & $\begin{array}{l}\text { Settlement } \\
\text { in } \mathrm{mm}\end{array}$ \\
\hline 0 & 0 & 0 & 0.03 \\
\hline 2.5 & 0.0567 & 2.5 & 0.05667 \\
\hline \multicolumn{4}{|c|}{ SECOND CYCLE } \\
\hline 0 & 0.03 & 0 & 0.085 \\
\hline 5 & 0.17 & 5 & 0.17 \\
\hline \multicolumn{4}{|c|}{ THIRD CYCLE } \\
\hline 0 & 0.085 & 0 & 0.13 \\
\hline 5 & 0.19 & 5 & 0.2 \\
\hline 7.5 & 0.25 & 7.5 & 0.25 \\
\hline \multicolumn{4}{|c|}{ FOURTH CYCLE } \\
\hline 0 & 0.13 & 0 & 0.22 \\
\hline 5 & 0.17 & 5 & 0.285 \\
\hline 10 & 0.365 & 10 & 0.365 \\
\hline \multicolumn{4}{|c|}{ FIFTH CYCLE } \\
\hline 0 & 0.22 & 0 & 0.365 \\
\hline 5 & 0.235 & 5 & 0.435 \\
\hline 10 & 0.285 & 10 & 0.49 \\
\hline 15 & 0.52 & 15 & 0.52 \\
\hline
\end{tabular}

\section{List of Figures:}

Figure 1: Load V/s Settlement Curve (Un Reinforced)

Figure 2: Load V/s Settlement Curve (Reinforced)

Figure 3: Cyclic Loading Curve to evaluate Co efficient of Elastic Uniform Compression of sand.

Figure 4: Determination of the coefficient of uniform compression $\mathrm{Cu}$ of Unreinforced sand.

Figure 5: Cyclic loading Curve to Evaluate Co efficient of elastic Uniform compression of sand reinforced with fiber

Figure 6: Determination of the coefficient of uniform compression $\mathrm{Cu}$ of reinforced sand

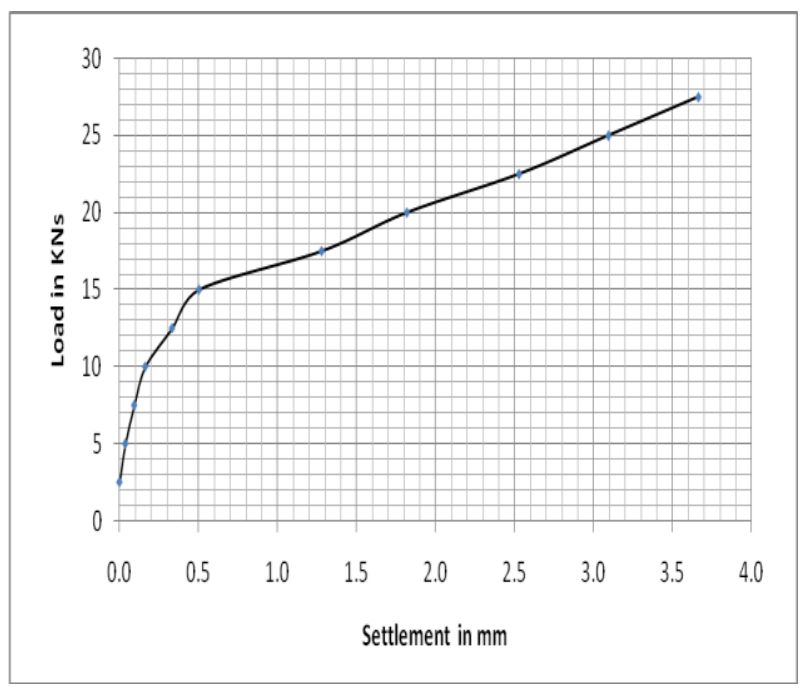

Fig1- Load V/s Settlement Curve (Un Reinforced sand) 


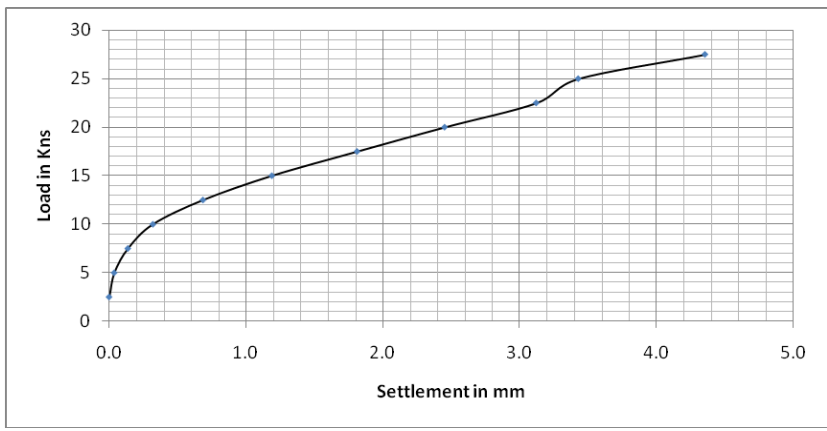

Fig 2 - Load v/s Total Settlement Curve (Fiber Reinforced Sand)

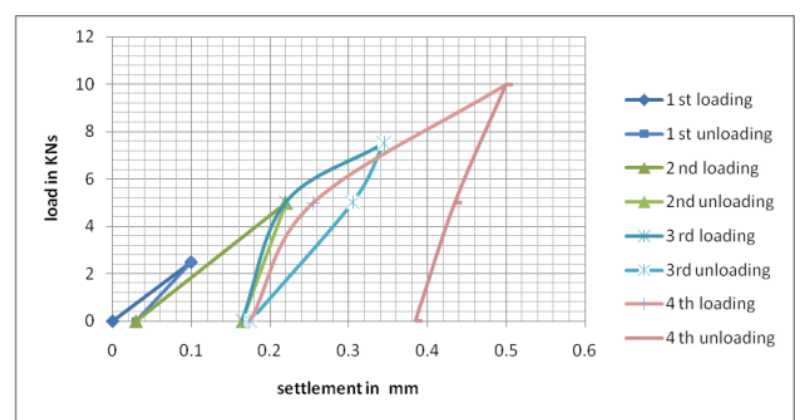

Fig 3- Cyclic Loading Curve to evaluate Co efficient of Elastic Uniform Compression of Un reinforced sand.

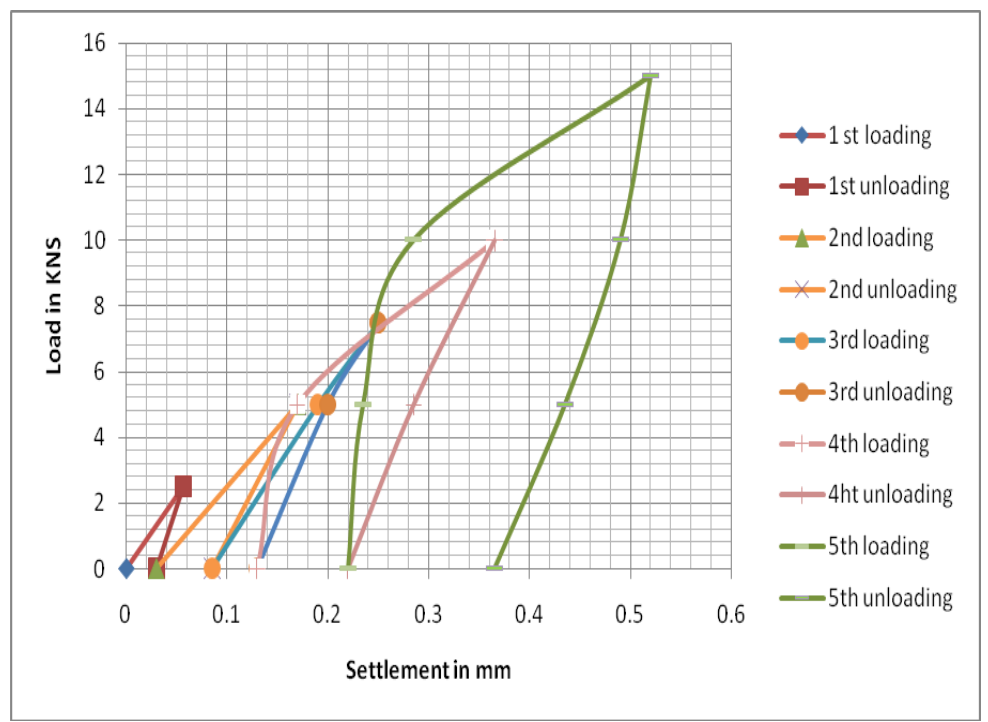

Fig 4- Cyclic loading to Evaluate Co efficient of elastic Uniform compression of sand reinforced with fiber

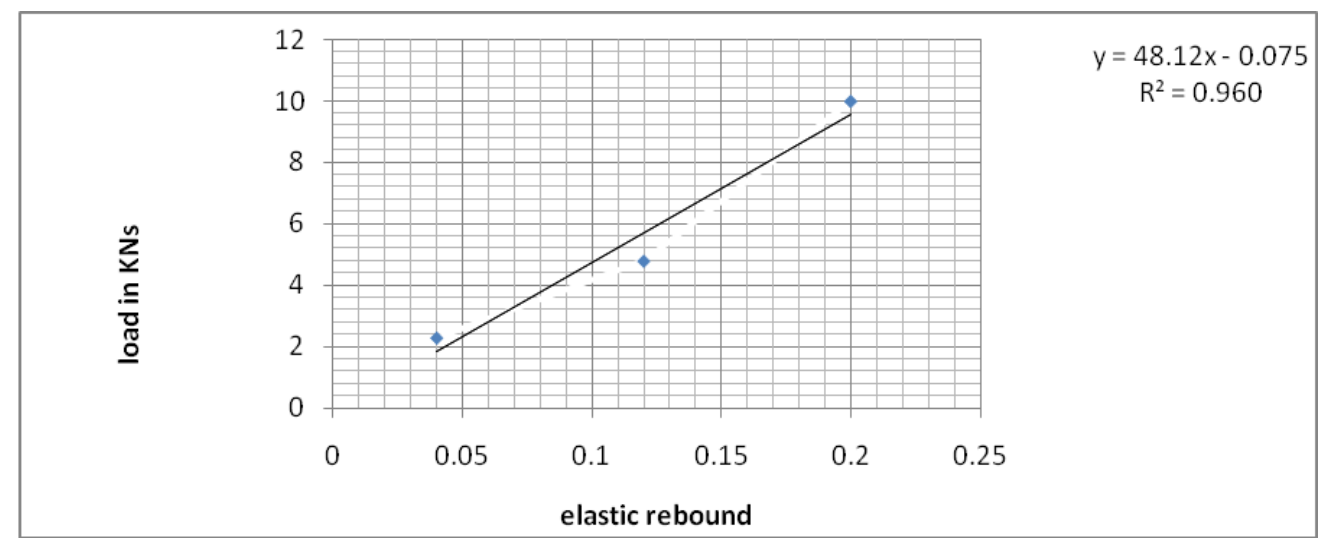

Fig 5 Determination of the coefficient of uniform compression $(\mathrm{Cu})$ of Unreinforced sand. 


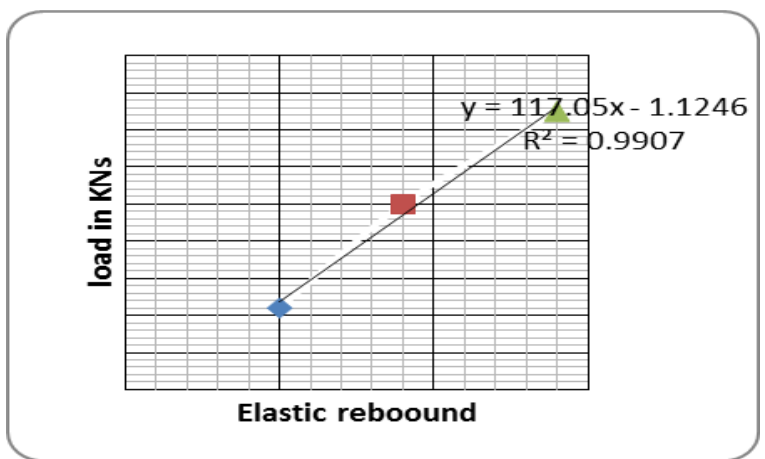

Fig 6 Determination of the coefficient of uniform compression $\mathrm{Cu}$ of reinforced sand.

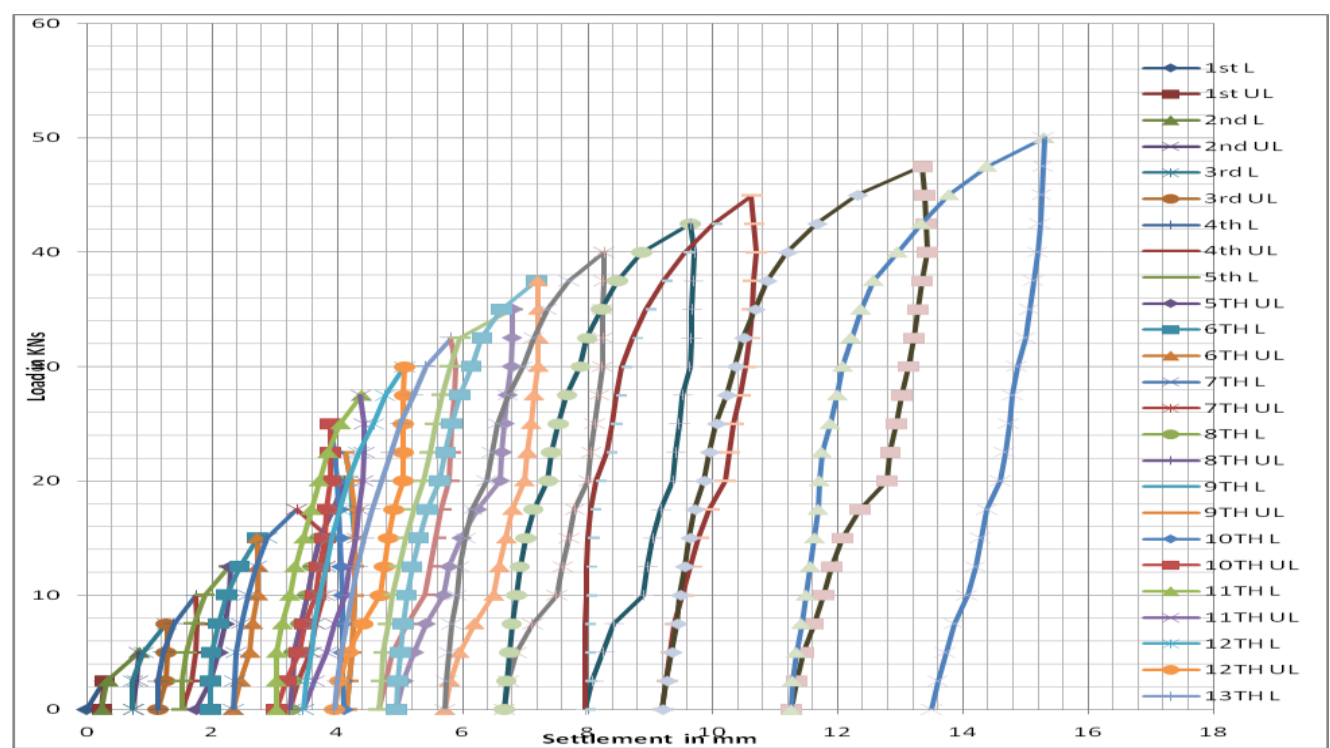

Fig 7- Cyclic loading to Evaluate Co efficient of elastic Uniform compression of Black cotton soil.

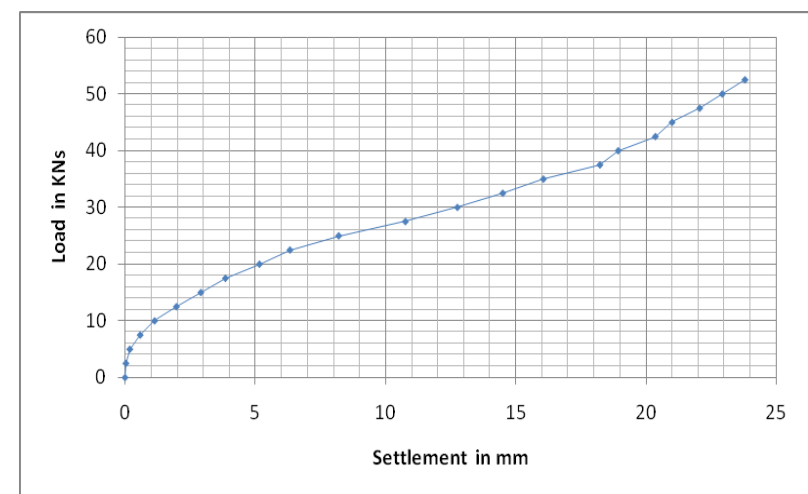

Fig8- Load V/s Settlement Curve on Black cotton soil

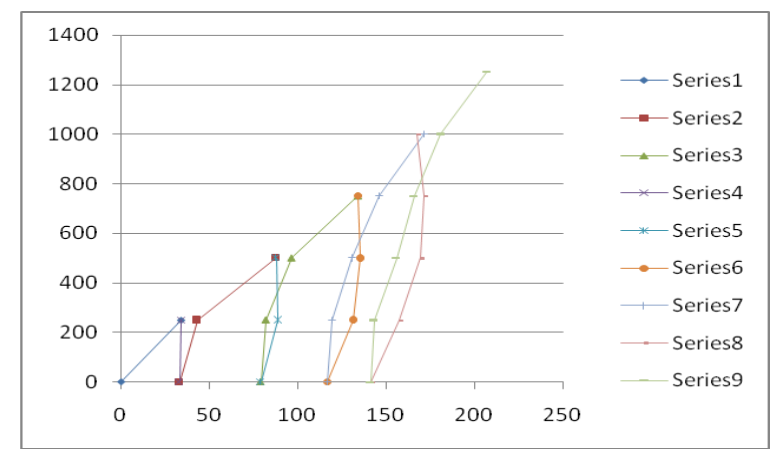

Fig 9-Cyclic plate load test on BC Soil Added with Stabiliser 


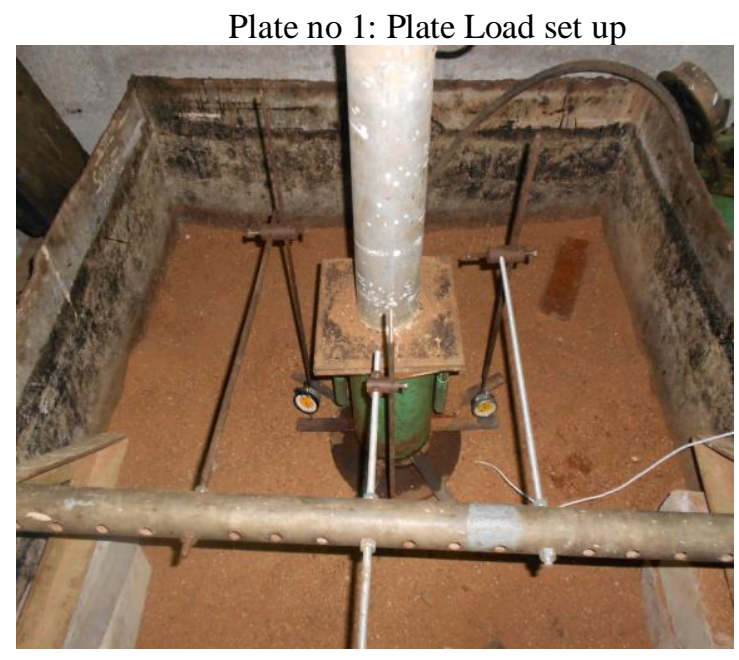

\section{CONCLUSION.}

The conclusions based on this study can be summarized as follows:-

1. The static bearing capacity increases and the settlement values decreases by fiber reinforcement.

2. The dynamic characteristics of sand can be effectively modified by reinforcing fibers.

3. Co efficient of Elastic Uniform compression $\mathrm{C}_{\mathrm{u}}$ and $\mathrm{CBR}$ increases with the introduction of fiber reinforcement.

4. The sand fiber composites have either a curved linear or a bilinear failure Envelop.

5. From literature review Verma et al., the reinforced sand bed has more damping capacity than that of unreinforced sand bed.

6. The Modulus of subgrade Reaction $(\mathrm{K})$ is more in fiber reinforced sand than unreinforced sand

\section{REFERENCES}

[1] Donald H.Gray. and Talal Al-Refeai. (August, 1986). "Behavior of Fabric-Versus Fiber-Reinforced Sand," Int. Jon. of Geotechnical Engineering Vol.112, No.8.

[2] Gabr. M.A. and John H.Hart. (June, 2000). "Elastic Modulus of Geogrid-Reiforced Sand Using Plate load tests," Geotechnical Testing Journal, GTJODJ, Vol.23, No 2, PP-245-250.

[3] Gray.D.H. and Ohashi.H. (1983). "Mechanics of fiber reinforcement in sand "Jon. Geotechnical Engg., ASCE, 109(3), pp 335-353.

[4] Gray.D.H. and Maher.M.H.(1989). "Admixture stabilization of sands with discrete, randomly distributed fibers”. Proc., XII Int. Conf. on soil Mech. And Found. Engg.

[5] Moghaddas Tafreshi.S.N., Zarei.S.E. and Soltanpour.Y. (October 12-17, 2008). "Cyclic Loading on Foundation to Evaluate the Coefficient of Elastic Uniform compression of sand," The 14 ${ }^{\text {th }}$ World Conference on earth quake engineering, Beijing, China.

[6] Rosa L. Santoni. and Steve L.Webster. (March/April2001). "Airfield and Roads Construction Using Fiber stabilization of Sands," Int. Jon. of transportation Engineering.

[7] Radoslaw L.Michalowski and Jan Cermak. (February, 2003). "Triaxial Compression of Sand Reinforced with Fibers," Int. Jon. of Geotechnical and Geoenvironmental Engineering.

[8] Rosa L. Santoni. and Steve L.Webster. (March, 2001). "Engineering Properties of sand- Fiber Mixtures for Road Construction," Int. Jon. of Geotechnical and Geoenvironmental Engineering.

[9] Ranjan.G., Vasan.R.M. and Charan.H.D.(1996). "Probabilistic analysis of Randomly Distributed FiberReinforced Soil.” Jon. Geotech.Engg., ASCE,122(6),419-426.

[10] Is.1888: (1982). "Indian Standard Method of Load Test on Soils,"BIS, New Delhi, India.

[11] Is.5249: (1992). "Indian Standard method of Test for Determination of Dynamic Properties of Soils," BIS, New Delhi, India. 